\title{
ATP-Dependent RNA Helicase DDX3X
}

National Cancer Institute

\section{Source}

National Cancer Institute. ATP-Dependent RNA Helicase DDX3X. NCI Thesaurus. Code C101567.

ATP-dependent RNA helicase DDX3X (662 aa, $73 \mathrm{kDa}$ ) is encoded by the human DDX3X gene. This protein is involved in the regulation of RNA structure, localization and metabolism. 